\title{
Investment Property Measurement at Fair Value in the Financial Statements
}

\author{
Kulikova L.I.a \\ Samitova A.R. ${ }^{b}$ \\ Aletkin P.A.c \\ a bc Kazan Federal University, Institute of Management, Economics and Finance, Kazan, 420008, Russia
}

\section{Doi:10.5901/mjss.2015.v6n1s3p401}

\begin{abstract}
The paper investigates the problems of the applicability of the investment property measurement at fair value for financial reporting purposes by Russian companies. Based on the analysis of the annual consolidated financial statements of bank institutions in Russian Federation, compiled by international standards, we find that most of the companies applied valuation of investment property at fair value. Our findings also indicate that most of the companies address to independent appraisal for investment property measurement at fair value using market approach. In our research we examined different techniques to investment property measurement based on the income capitalization approach and discounted future cash flows. This allows to accumulate the information about the fair value of investment property for the purposes of financial statements compilation.
\end{abstract}

Keywords: investment property, fair value, historical cost, income approach, market approach

\section{Introduction}

The issues of accounting for investment property considering country-specific factors were addressed by many researchers: Bûmane, I. and Kasale, M. [1], Babawale, G.K. [2], Dong, Z. and Li, N. [3], So, S. and Smith, M. [4].

In the accounting literature the fair value measurement applicability is one of the most widely debated issues especially in the conditions of world economic crisis. The issue was addressed by Beaudoin, C.A. and Hughes, S.B. [5], Macve, R.H. [6], Kulikova L.I. and Goshunova A.V. [7], Cairns, D., Massoudi, D., Taplin, R. and Tarca, A. [8], Costa, M. and Guzzo, G. [9] and others. The complexities of fair value applicability to nonfinancial assets were examined by Christensen, H.B. and Nikolaev, V.V. [10], Linsmeier, T.J. [11], Diehl, K.A. [12], Hlaing, K.P. and Pourjalali, H. [13], and applicability to investment property in particularly by Haaker, A. and Schiffer, T. [14], Quagli, A. and Avallone, F. D. [15], Kulikova L.I. $[16,17]$.

The objective of the study is to investigate the practical application of fair value methods for investment property measurement in Russian Federation and to develop practical recommendations for preparing financial statements.

\section{Method}

There is a cautious attitude towards the use of fair value approach as a measurement method of nonfinancial assets not only among researchers but among practitioners as well. As evidence supporting this point of view the data from a number of studies can be provided.

According to a study conducted by Diehl, K.A. [12] in 2009 among the companies whose shares comprise FTSE 100 (UK), only $11 \%$ respondents use fair value measurement of property, plant and equipment. Of this amount $64 \%$ is of the financial sector and $36 \%$ is of non-financial sector.

Hlaing, K.P. and Pourjaalli, H. [13] based on the analysis of financial statements of the foreign-listed firms in the US Stock Exchanges points out that only 38 of 232 firms chose to report their fixed assets at fair value (16\% of the sample). The researchers suggest the existence of direct correlation between the intent to use fair value methods and the size of the company, ratio of the total amount of property, plant and equipment to total assets.

However, as noted by Fargher, N. and Zhang, J.Z. [18], there is a tendency to greater use of fair value by the management of companies as an opportunity to achieve maximum reliability of the information recorded in the financial statements.

The similar approach in IAS 40 «Investment property» can be found. Despite the fact that the standard allows two 
models of investment property accounting subsequent to initial recognition: a fair value model and a cost model, preference is given to the first model, as it will contribute most to the best presentation of information in the financial statements. It is unlikely that the transition from a fair value model to a cost model to provide better representation of information.

The fair value definition, fair value measurement methods and disclosure to measurement approaches are in IFRS 13 «Fair value measurement» considered.

\section{Results}

We have conducted analysis of the annual consolidated financial statements for the 50 Russian banks with the highest value of net assets for the year ended 31 December 2013 in order to identify interest in buying investment property, to study methods for determining fair value and to disclose the information in financial statements in compliance with IAS 40 and IFRS 13.

In our sample the investment property is present in 30 financial reports (60\% of the sample). The information about the model applied in the accounting for investment property is presented in Table 1.

Table 1. Investment property existence in financial statements

\begin{tabular}{|c|c|c|}
\hline Chosen model of accounting & Number of companies & Percentage to total \\
\hline Fair value model & 21 & 70 \\
\hline Cost model & 9 & 30 \\
\hline Total & 30 & 100 \\
\hline
\end{tabular}

Regardless of the chosen model of accounting for investment property, IAS 40 requires from all the companies to determine the fair value of investment property either for measurement purposes (if company chooses fair value model) or for disclosure of information (if the company chooses cost model).

The definition of the fair value applied to investment property is disclosed in accounting policies of virtually all the companies from the sample. Some companies have used the terminology from IAS 40 as of 2008 which stated that fair value is the amount for which an asset could be exchanged, or a liability settled, between knowledgeable, willing parties in an arm's length transaction. Currently according to IFRS 13 fair value is the price that would be received to sell an asset or paid to transfer a liability in an orderly transaction between market participants at the measurement date.

We believe that the latter definition of fair value is a more complete one. The existence in the first definition of the terms "knowledgeable, willing and independent parties", in our opinion, does not contradict IFRS 13. Appendix A of IFRS 13 provides the characteristics of the market participants such as independence, knowledge, existence and desire to participate in the transaction.

In addition, some companies note in their reporting that the introduction of IFRS 13 has not led to any changes in the approach to the measurement of fair value, and resulted only in additional disclosures required by this standard.

In view of the foregoing, we consider consistent the application of terminology from IAS 40 (as of 2008) with the provisions of IAS 13 in the accounting policies of separate entities.

IAS 40 encourages but doesn't require from the company to determine fair value on a basis of an evaluation prepared by a duly qualified, independent evaluation expert who has a recent experience of appraisal for similar property in the same location. The chosen methods for evaluation by the practitioners are presented on the figure 1.
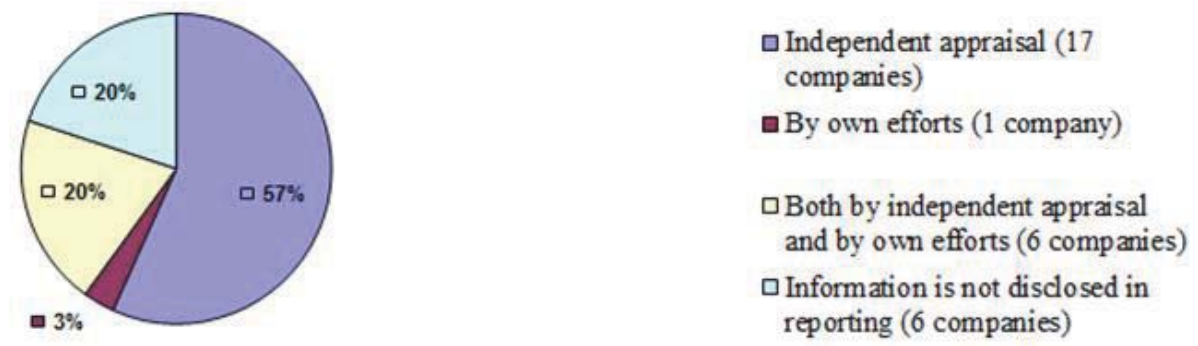

Fig. 1. Chosen methods of evaluation 
The figure indicates the preference for fair value measurement by an independent appraiser. Mostly this is due to the complexity of the procedure of the evaluation itself.

According to IFRS 13 one of the three valuation techniques in fair value measurement: market approach, cost approach, income approach or a combination of approaches can be used.

Most of the companies from our sample rely on the set of valuation methods but market approach is the most heavily used. The corresponding data is presented on figure 2 .

Applying income approach fair value was determined on the basis of both capitalization of income and discounting of future income. Both approaches are approximately equally distributed among the companies.
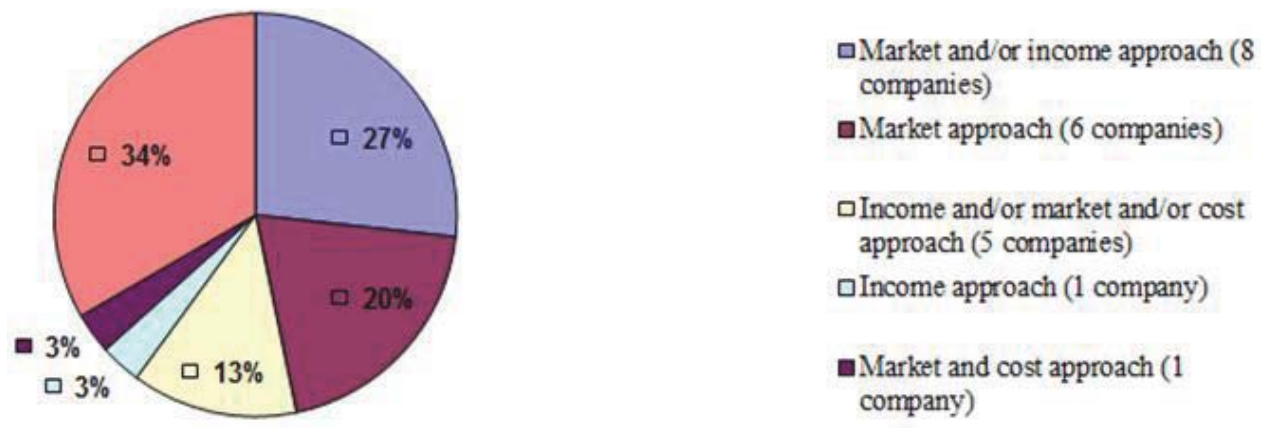

Fig. 2. Valuation techniques applied for investment property measurement at fair value

In applying of capitalization of income the fair value of investment property is determined by conversion of yearly net operating income into the current cost according to a formula:

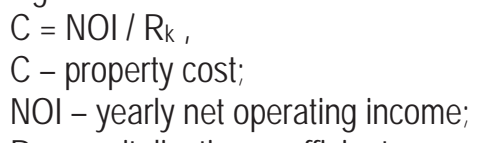

In application of capitalization of income method the companies used following key assumptions:

1) net income in the base year was calculated using information on actual rental rates, potential losses from vacancy rates of the investment property, costs for maintenance of the investment property;

2) the losses from vacancy rates of the investment property calculated as a share of potential gross income from the lease ranged from $2 \%$ to $10 \%$ and in some cases to $30 \%$;

3) for the purpose of capitalization of net income for the base year a capitalization rate ranged from $9 \%$ to $14 \%$ was used;

4) the share of general and administrative expenses on the maintenance of the buildings was estimated between $10 \%$ to $15 \%$ of gross income from the lease;

5) for the purpose of capitalization of net income for the base year for land higher rates of capitalization up to $20 \%$ were applied.

Determining the value of the investment property based on discounting can be addressed in a simplified form by the formula:

$C=\sum_{j=1}^{n} \frac{\mathrm{NOIj}}{(1+i)^{j}}$

$\mathrm{C}$ - investment property cost;

$\mathrm{NOl}_{j}$ - net operating income for the j-year;

$\mathrm{i}$ - discounting rate;

$\mathrm{n}$ - anticipated holding period.

At the same time used the following key assumptions are not observable in the market:

1) discounting rate in order to correct the discrepancies in the location, floor space, class and conditions of compared objects ranged from $0 \%$ to $15 \%$;

2) average discounting rate $-14 \%$.

IFRS 13 establishes fair value hierarchy which divides the inputs used in valuation techniques into three levels. The hierarchy gives the highest priority to (unadjusted) quoted prices in active markets for identical assets or liabilities 
(level 1 inputs) and the lowest priority to unobservable inputs (level 3 inputs).

According to our sample the hierarchy is presented by level 2 inputs (4 companies -13,3\%) and by level 3 inputs (15 companies - 43,3\%), 11 companies preferred not to disclose the information in financial statements. The attribution of the inputs predominantly to the level 3 is determined by the specifics of investment property and indicates underdevelopment of Russia's real estate market.

An additional point is that in measuring investment property at fair value the specific characters of this kind of assets must be taken into the account. In determining the fair value of investment property one need to keep in mind that separate assets are included in this value. For instance, equipment is included in fair value of the building as an investment property and it is not shown separately as fixed asset, the cost of furniture is included in fair value of an office as an investment property because the rental charges are taken for furnished office.

In the fair value of investment property is not included prepayment or accrued income under an operating lease as companies disclose these items separately as liabilities or assets.

The fair value of the leased investment property shows expected cash flows, including contingent rent which is expected to receive.

Accordingly if the assessment of the property is made as net of any expected payments, in order to account for the fair value of investment property the value of any recognized lease liability should be added to this amount.

In the situation when the present value of the payments made by the company for the investment property exceeds the present value of the related cash flows it is need to determine whether the liability arises in the company and to estimate the liability in accordance with IAS 37 "Provisions, Contingent Liabilities and Contingent Assets".

\section{Conclusion}

Our analysis of the consolidated financial statements revealed deficiencies in the disclosure of information in accordance with IAS 40 and IFRS 13 in respect of investment property held by individual companies in the Russian Federation. Not all the companies disclose the information in respect of those conducting the appraisal of real estate, the information about valuation techniques and key assumptions, levels of the hierarchy of information.

\section{References}

Bûmane, I., Kasale, M. Accounting policy of investment property - The case of Latvia // Ekonomska Istrazivanja SPEC. ISS. 1, 2012. pp. 27-46.

Babawale, G.K. Paradigm shift in investment property valuation theory and practice: Nigerian practitioners' response // Mediterranean Journal of Social Sciences 3 (3), 2012. pp. 217-228.

Dong, Z., Li, N.Document Investment property diversification over different economic phases in New Zealand // Pacific Rim Property Research Journal 18 (2), 2012. pp. 106-128.

So, S., Smith, M. Value-relevance of presenting changes in fair value of investment properties in the income statement: Evidence from Hong Kong // Accounting and Business Research 39 (2), 2009. pp. 103-118.

Beaudoin, C.A., Hughes, S.B. An application of impairment testing and fair value estimation using international financial reporting standards // Accounting Education 29 (1), 2014. pp. 181-189.

Safiullin L.N., Gafurov I.R., Shaidullin R.N., Safiullin N.Z. Socio-economic development of the region and its historical and cultural heritage. Life Science Journal 2014; 11(6s): 400-404.

Macve, R.H. Fair value vs conservatism? Aspects of the history of accounting, auditing, business and finance from ancient Mesopotamia to modern China // British Accounting Review, 2014.

Kulikova L.I., Goshunova A.V. Measuring efficiency of professional football club in contemporary researches // World Applied Sciences Journal 25 (2), 2013. pp. 247-257.

Cairns, D., Massoudi, D., Taplin, R., Tarca, A. Document IFRS fair value measurement and accounting policy choice in the United Kingdom and Australia // British Accounting Review 43 (1), 2011. pp. 1-21.

Costa, M., Guzzo, G. Fair value accounting versus historical cost accounting: A theoretical framework for judgment in financial crisis // Corporate Ownership and Control 11 (1 I), 2013. pp. 146-152.

Christensen, H.B., Nikolaev, V.V. Does fair value accounting for non-financial assets pass the market test? // Review of Accounting Studies 18 (3), 2013. pp. 734-775.

Linsmeier, T.J. A Standard setter's framework for selecting between fair value and historical cost measurement attributes: A basis for discussion of "Does fair value accounting for nonfinancial assets pass the market test?" // Review of Accounting Studies 18 (3), 2013. pp. 776-782.

Diehl, K.A. Cost or fair value: FTSE 100 response to IFRS IAS 16's choice on treatment of property, plant, and equipment and the implications for US companies // European Journal of Economics, Finance and Administrative Sciences 16, 2009. pp. 66-73.

Safiullin L.N., Novenkova A.Z., Safiullin N.Z., Ismagilova G.N. Prospects of small business in Tatarstan. Life Science Journal 2014; 
11(6s): $396-399$.

Hlaing, K.P., Pourjalali, H. Economic reasons for reporting property, plant, and equipment at fair market value by foreign cross-listed firms in the United States // Journal of Accounting, Auditing and Finance 27 (4), 2012. pp. 557-576.

Haaker, A., Schiffer, T. Die nutzung des fair-value-wahlrechts für investment properties im lichte von kapitalmarktinformation, managementinteresse und bewertungsproblemen | [Impact of the fair value option for investment properties on capital market information, management's interest and valuation problems] // Betriebswirtschaftliche Forschung und Praxis 4, 2014. pp. 387403.

Quagli, A., Avallone, F. Document Fair value or cost model? Drivers of choice for IAS 40 in the real estate industry // European Accounting Review 19 (3), 2010. pp. 461-493.

Kramin M.V., Safiullin L.N., Kramin T.V., Timiryasova A.V. Drivers of economic growth and investment attractiveness of Russian regions. Life Science Journal 2014; 11(6s): 526 - 530.

Fargher, N., Zhang, J.Z. Changes in the measurement of fair value: Implications for accounting earnings // Source of the Document Accounting Forum 38 (3), 2014. pp. 184-199. 